\title{
Effect of Microbial Inoculation and Bentonite Amendments on Growth, Enzyme Activity and Yield of Cowpea Cultivated in Sandy Soil
}

\author{
Shebl Abd-Allah Abd-elgwad \\ Soils, Water and Environment Research Institute (SWERI), Agricultural Research \\ Center, Giza, Egypt.
}

\begin{abstract}
A FIELD experiment was conducted twice at the farm of Environmental Studies and Research Institute, Sadat City University, Egypt, during the two consecutive seasons of 2015 and 2016 to study the effect of different additives of bentonite (i.e., 0, 3, 6 and $9 \mathrm{t} \mathrm{fed}^{-1}$ ), and microbial inoculation with Bradyrhizobium sp. and Azospirillum brasilense either alone or mixed on vegetative parameters, enzyme activity and yield of cowpea plants. Results revealed that co-inoculation treatment and addition of $9 \mathrm{Mg} \mathrm{fed}^{-1}$ bentonite significantly enhanced plant height, number of branches, fresh and dry weight of plant in both seasons compared with the control at 60 days from sowing and this increase reflected on enzyme activity which attained 25.56, $27.66 \mu \mathrm{mol} / \mathrm{C}_{2} \mathrm{H}_{4} / \mathrm{h} / \mathrm{g}$ dry nodules and 50.93, $54.57 \mu \mathrm{g} \mathrm{TPF} / \mathrm{g}$ dry soil/h for nitrogenase $\left(\mathrm{N}_{2}\right.$-ase) and dehydrogenase in the two growing seasons, respectively. On the other hand, the highest total seed yield of cowpea was recorded from use the co-inoculation with 9 ton ton/fed which was 0.679 and $0.682 \mathrm{Mg} \mathrm{fed}^{-1}$ for seed yield and 0.316, $0.324 \mathrm{Mgfed}^{-1}$ for straw yield during 2015 and 2016 seasons, respectively. Consequently, it is to recommend that mixture inoculate with Bradyrhizobium sp. and Azospirillumbrasilense and addition of $9 \mathrm{Mg} \mathrm{fed}^{-1}$ bentonite could be improving crop growth of cowpea and improve sandy soil fertility.
\end{abstract}

Keywords: Cowpea, Microbial inoculation, Bentonite, Enzyme activity, Yield.

\section{Introduction}

Cowpea (Vignasinensis) is an individual of fabaceae family and one of the most essential vegetable crops in Egypt. Seeds represent a chief source of protein and carbohydrates content. It globally has a considerable rank in agriculture with about 270 million tons harvested of 12.2 million planted area $\mathrm{ha}^{-1}$ as a potential production. In Egypt, Cowpea consider as a main crop, where its planted area is about 0.178 million ha ${ }^{-1}$ with production is about 4.80 million tons (FAO 2013).

Sandy soils are known to have a low productivity due to their poor physical and chemical properties. Incorporation of soil conditioners to these soils was reported to create a favorable environment for plant growth, such as sufficient aeration, suitable retention of water and nutrients as well as restricting the formation of surface crust (Asady et al.1985; Stone,1985).

Likewise, organic manures, composts and bentonite have been used in Egypt as natural soil conditioners which for reclaiming sandy soils. Bentonite is a rock containing mainly 2:1 clay mineral montmorillonite, a member of the semectite family which has been recognized in many countries as a good amendment to improve such infertile sandy soil Benkhelifa et al. (2008). Czaban et al. (2013) found that, the addition of bentonite at rates of 3,6 and $12 \mathrm{~kg} / \mathrm{m}^{2}$ of soil significantly improved soil structure and increased the amounts of nitrogen and organic matter in sandy soils. According to Mi et al. (2017), the addition bentoniteas amendment on soil hydraulic parameters and millet crop performance in a semiarid region significantly increased above-ground biomass and grain yield and improved water use efficiency. They stated that increases ranges were 2 to 39,3 to 20 and 0 to $29 \%$ for aboveground biomass increases, grain yield and water use efficiency. They add that the application of $24 \mathrm{Mg} \mathrm{ha}^{-1}$ bentonite recorded the greatest effect over five years with maximum rate of $30 \mathrm{Mg} \mathrm{ha}^{-1}$

Corresponding author e-mail: abdelgwadshebl@yahoo.com

DOI: 10.21608/JENVBS.2019.9954.1055

(C2019 National Information and Documentation Center (NIDOC) 
in the fifth year of the experiment which showed the greatest effect.

An excellent combination of traits useful in disease control and plant growth promoting rhizobacteria (PGPR) was first defined by Kloepper and Schroth (1978) where the soil bacteria colonize the roots of plants. Tilak et al. (2005) documented that PGPRs, belong to diverse genera of Azospirillum, Alcaligenes, Arthrobacter, Enterobacter, Erwinia, Acinetobacter, Bacillus, Burkholderia, Flavobacterium, Pseudomonas, Rhizobium and Serratia, are able to exert beneficial effects on plant growth.

According to Xie et al. (2009), Tejada et al. (2011) and Omara et al. (2017), the assessment of soil dehydrogenase activity (DHA) indicated the microbial activity as indicator of soils quality as well as for determining the various factors that affect the microbiological quality of soils such as different application of pollutants like pesticides or excessive fertilizers usage. Also in such context, the determination of dehydrogenase activity DHA in the soil samples could potentially give us useful and large amount of information about biological characteristic of the soil because it is influenced by various other factors present in the soil environment, like moisture, availability of oxygen, reduction-oxidation potential, $\mathrm{pH}$, content of organic matter, the soil profile depth, temperature, season of the year and heavy metal contamination (Wolińska and Stępniewska 2012).

Therefore, the objectives of the current study were to investigate the effect of three levels of bentonite and microbial inoculation either alone or mixed on cowpea vegetative growth characteristics, enzyme activity and yield.

\section{Materials and Methods}

Two field experiments were executed at the farm of Environmental Studies and Research, Institute, Sadat City University during the two consecutive summer seasons of 2015 and 2016, under system of drip irrigation, to study the effect of bentonite rate amendments $(0,3,6$ and $9 \mathrm{Mg} /$ fed) as a soil conditioner and bacterial inoculation Bradrhizobium sp. and Azospirillumbasilenes either alone or mixed on vegetative growth, yield and microbial activity in the rhizosphere of cowpea cv. Kareem 7 under sandy soil conditions.

The site is located (Latitude $30^{\circ} 2^{\prime} 41.185^{\prime \prime} \mathrm{N}$; Longitude $31^{\circ} 14^{\prime} 8.1625^{\prime \prime} \mathrm{E}$ ), which is characterized by a semi-arid climate with moderate cold winters and warm summers. Physical and chemical properties of experiment soil used in experiment were determined according to the methods of Page et al. (1982) and their data are presented in Table 1. The experiment was performed in a spilt plots design in three replications.

TABLE 1. Analytical data of the soil used.

\begin{tabular}{|c|c|c|c|c|c|c|c|c|c|}
\hline \multicolumn{10}{|c|}{ Physical properties } \\
\hline \multirow{2}{*}{\multicolumn{2}{|c|}{$\begin{array}{c}\mathrm{CaCO}_{3} \\
\left(\mathrm{~g} 100 \mathrm{~g}^{-1}\right)\end{array}$}} & \multirow{2}{*}{\multicolumn{3}{|c|}{$\begin{array}{l}\text { Organic matter } \\
\quad\left({\left.\mathrm{g} 100 \mathrm{~g}^{-1}\right)}^{-1}\right.\end{array}$}} & \multicolumn{3}{|c|}{ Particle size (\%) } & \multirow{2}{*}{\multicolumn{2}{|c|}{$\begin{array}{c}\text { Texture } \\
\text { class }\end{array}$}} \\
\hline & & & & & Sand & Silt & Clay & & \\
\hline \multicolumn{2}{|c|}{19.0} & \multicolumn{3}{|c|}{3.0} & 88.6 & 4.8 & 6.6 & \multicolumn{2}{|c|}{ Sandy } \\
\hline \multicolumn{10}{|c|}{ Chemical Properties } \\
\hline \multirow{2}{*}{$\mathbf{P H}^{*}$} & \multirow{2}{*}{$\begin{array}{c}E C^{* *} \\
d S m^{-1}\end{array}$} & \multicolumn{4}{|c|}{ Soluble cations (meq/L) } & \multicolumn{4}{|c|}{ Soluble anions (meq/L) } \\
\hline & & $\mathrm{Ca}^{++}$ & $\mathbf{M g}^{++}$ & $\mathbf{K}^{+}$ & $\mathbf{N a}^{+}$ & $\mathrm{CO}_{3}^{--}$ & $\mathrm{HCO}_{3}^{-}$ & $\mathrm{Cl}^{-}$ & $\mathrm{SO}_{4}^{-}$ \\
\hline 7.63 & 1.82 & 0.36 & 0.32 & 0.14 & 0.56 & - & 0.41 & 0.36 & 0.61 \\
\hline
\end{tabular}

*In the 1:2.5 Soil: water suspension. $\quad * *$ In the soil paste extract.

Main plot consists of four levels of bentonite amendment $(0,3,6$ and $9 \mathrm{Mg} /$ fed.), the bentonite had a chemical composition on a weight basis of : $73.25 \% \mathrm{SiO}_{2}, 11.4 \% \mathrm{Al}_{2} \mathrm{O}_{3}, 0.31 \% \mathrm{Na}_{2} \mathrm{O}, 2.67 \%$ $\mathrm{CaO}, 1.05 \% \quad \mathrm{MgO}, 2.58 \% \quad \mathrm{~K}_{2} \mathrm{O}, 0.29 \% \quad \mathrm{Fe}_{2} \mathrm{O}_{3}$ and the practical size was $75 \mu \mathrm{m}$. Bentonite was adding before planting, while bacterial

Env. Biodiv. Soil Security Vol. 3 (2019) inoculation in subplots with un-inoculated (control), Bradrhizobium sp, A. basilenes and coinoculation. Seeds were treated with microbial inoculant suspension before sowing for one hour and shade dried for one hour. Seeds were planted during $14^{\text {th }}$ of April in the two years in plot area $9.0 \mathrm{~m}^{2}$. 
All treatments received the recommended dose of superphosphate $\left(15.5 \% \mathrm{P}_{2} \mathrm{O}_{5}\right)$ at a rate of $200 \mathrm{~kg} / \mathrm{fed}$., potassium sulfate $\left(48 \% \mathrm{~K}_{2} \mathrm{O}\right)$ at a rate of $50 \mathrm{~kg} /$ fed before sowing (as one dose). Nitrogen fertilizer application added as a form of ammonium nitrate $(33.5 \% \mathrm{~N})$ at rate $60 \mathrm{Kg} /$ fed (full dose) to control only. The rest of the treatments added half of the recommended dose of nitrogen fertilizer. Added at two equal doses, the first at three weeks after sowing, the second after 15 from the previous one.

\section{Data recorded}

Vegetative growth character

Three plants were taken randomly from each replicate at flowering (60 days after sowing) to measure the following vegetative characters i.e. plant height $(\mathrm{cm})$, number of branches, fresh and dry weight/plant (g).

\section{Yield component}

Weight of 100 seed, seed yield (ton/fed) and straw yield (ton/fed) were determined.

\section{Enzyme activities}

Fresh samples (soil and roots) were collected to determine enzyme activities.

- Dehydrogenase activity (DHA) was determined as described in Friedel et al. (1994) after soil incubation at $37^{\circ} \mathrm{C}$ for $24 \mathrm{~h}$ with 2,3,5-triphenyl-tetrazolium chloride (TTC) and the red color of triphenyl formazan (TPF) absorbance was measured at $546 \mathrm{~nm}$ using spectrophotometer.
- Nitrogenase activity $\left(\mathrm{N}_{2-}\right.$ ase $)$ was measured according to (Turner and Gibson, 1980).

\section{Statistical analysis}

All recorded data were subjected to ANOVA to identify significant treatments and/or interaction effects by ' $F$ test' using the SAS program (SAS Systems for Windows, release 9.2, SAS Institute, Cary, NC, SAS, 2003). Mean separation between the significant treatments was calculated by L.S.D.

\section{Results and Discussion}

Vegetative parameters of cowpea plants

Data in Table, 2 and 3 show the effect of bentonite amendment and bacterial inoculation and their interaction on plant height, number of branches and fresh and dry weight/plant. All the studied vegetative growth characters showed significantly increases with adding bentonite level up to $9 \mathrm{t} \mathrm{fed}^{-1}$ which scored significantly highest increase with all tested parameters. The highest level $9 \mathrm{t}$ /fed scored the tallest plants in both seasons but they were non-significant with using $6 \mathrm{t} \mathrm{fed}^{-1}$. Also, the highest level of bentonite amendment gave the high number of branches and weight of plants compared with zero amendment.

In this respect, Shalaby et al. (2005) found that, application of soil conditioners amendments such as chicken manure at rate of $10 \mathrm{~m}^{3} \mathrm{fed}^{-1}$ bentonite at rate 8 ton $\mathrm{fed}^{-1}$ and iron ore at rate of $200 \mathrm{Kg} \mathrm{fed}^{-1}$ combined with mineral fertilizers at rates $75 \mathrm{~kg} \mathrm{fed}^{-1} \mathrm{~N}, 22 \mathrm{~kg}$ fed $^{-1} \mathrm{P}_{2} \mathrm{O}_{5}$ and $72 \mathrm{~kg}$ fed $^{-1} \mathrm{~K}_{2} \mathrm{O}$ gave the highest vegetative growth components including plant height, number of

TABLE 2. Effect of bentonite amendments and microbial inoculation on some vegetative growth of cowpea cultivated in sandy soil.

\begin{tabular}{|c|c|c|c|c|c|c|c|c|}
\hline Treatments & \multicolumn{2}{|c|}{ Plant height $(\mathrm{cm})$} & \multicolumn{2}{|c|}{ No.branches/plant } & \multicolumn{2}{|c|}{ Fresh weight (g/plant) } & \multicolumn{2}{|c|}{ Dry weight (g/plant) } \\
\hline $\begin{array}{c}\text { Bentonite } \\
\text { rates(ton/fed.) }\end{array}$ & $\begin{array}{c}1^{\text {st }} \\
\text { Season }\end{array}$ & $\begin{array}{c}2^{\text {nd }} \\
\text { Season }\end{array}$ & $\begin{array}{c}1^{\text {st }} \\
\text { Season }\end{array}$ & $\begin{array}{c}2^{\text {nd }} \\
\text { Season }\end{array}$ & $\begin{array}{c}1^{\text {st }} \\
\text { Season }\end{array}$ & $2^{\text {nd }}$ Season & $\begin{array}{c}1^{\text {st }} \\
\text { Season }\end{array}$ & $\begin{array}{c}2^{\text {nd }} \\
\text { Season }\end{array}$ \\
\hline $\begin{array}{l}0 \\
3 \\
6 \\
9 \\
\end{array}$ & $\begin{array}{l}66.61 \mathrm{c} \\
71.72 \mathrm{~b} \\
74.64 \mathrm{a} \\
75.93 \mathrm{a} \\
\end{array}$ & $\begin{array}{c}67.75 \mathrm{~b} \\
67.70 \mathrm{~b} \\
75.23 \mathrm{ab} \\
76.53 \mathrm{a} \\
\end{array}$ & $\begin{array}{l}2.83 \mathrm{c} \\
3.08 \mathrm{~b} \\
3.27 \mathrm{ab} \\
3.46 \mathrm{a} \\
\end{array}$ & $\begin{array}{l}3.04 \mathrm{~b} \\
3.52 \mathrm{a} \\
3.35 \mathrm{a} \\
3.56 \mathrm{a} \\
\end{array}$ & $\begin{array}{l}125.87 \mathrm{~d} \\
144.19 \mathrm{c} \\
163.97 \mathrm{~b} \\
181.23 \mathrm{a} \\
\end{array}$ & $\begin{array}{l}118.85 \mathrm{~d} \\
148.19 \mathrm{c} \\
173.23 \mathrm{~b} \\
189.07 \mathrm{a} \\
\end{array}$ & $\begin{array}{l}56.74 \mathrm{~d} \\
66.18 \mathrm{c} \\
76.34 \mathrm{~b} \\
80.51 \mathrm{a} \\
\end{array}$ & $\begin{array}{l}61.30 \mathrm{~d} \\
67.05 \mathrm{c} \\
78.41 \mathrm{~b} \\
83.64 \mathrm{a} \\
\end{array}$ \\
\hline LSD at $5 \%$ & $\begin{array}{c}2.18 \\
\mathbf{1}^{\text {st }} \\
\text { Season }\end{array}$ & $\begin{array}{c}8.47 \\
2^{\text {nd }} \\
\text { Season }\end{array}$ & $\begin{array}{c}3.16 \\
1^{\text {st }} \\
\text { Season }\end{array}$ & $\begin{array}{c}0.237 \\
\mathbf{2}^{\text {nd }} \\
\text { Season }\end{array}$ & $\begin{array}{c}7.49 \\
\mathbf{1}^{\text {st }} \\
\text { Season }\end{array}$ & $\begin{array}{c}6.43 \\
2^{\text {nd }} \text { Season }\end{array}$ & $\begin{array}{c}2.45 \\
\mathbf{1}^{\text {st }} \\
\text { Season }\end{array}$ & $\begin{array}{c}2.61 \\
2^{\text {nd }} \\
\text { Season }\end{array}$ \\
\hline $\begin{array}{c}\text { Control } \\
\text { B } \\
\text { A } \\
\text { Mixture }\end{array}$ & $\begin{array}{c}69.66 \mathrm{c} \\
71.45 \mathrm{~b} \\
73.96 \mathrm{a} \\
70.03 \mathrm{bc}\end{array}$ & $\begin{array}{c}70.19 \mathrm{c} \\
72.60 \mathrm{~b} \\
74.75 \mathrm{a} \\
71.15 \mathrm{~b}\end{array}$ & $\begin{array}{l}2.68 \mathrm{~d} \\
3.03 \mathrm{c} \\
3.15 \mathrm{~b} \\
3.38 \mathrm{a}\end{array}$ & $\begin{array}{l}2.77 \mathrm{~d} \\
3.08 \mathrm{c} \\
3.36 \mathrm{~b} \\
3.47 \mathrm{a}\end{array}$ & $\begin{array}{l}128.65 \mathrm{c} \\
148.63 \mathrm{~b} \\
152.32 \mathrm{~b} \\
174.15 \mathrm{a}\end{array}$ & $\begin{array}{l}129.62 \mathrm{c} \\
157.02 \mathrm{~b} \\
161.71 \mathrm{~b} \\
182.81 \mathrm{a}\end{array}$ & $\begin{array}{c}60.53 \mathrm{c} \\
66.78 \mathrm{~b} \\
68.72 \mathrm{ab} \\
70.57 \mathrm{a}\end{array}$ & $\begin{array}{c}61.38 \mathrm{c} \\
68.73 \mathrm{~b} \\
70.36 \mathrm{ab} \\
72.62 \mathrm{a}\end{array}$ \\
\hline LSD at $5 \%$ & 1.526 & 1.239 & 0.079 & 0.0608 & 6.634 & 4.908 & 2.448 & 2.514 \\
\hline
\end{tabular}

In a column means followed by a common letter are not significantly different at $5 \%$ level by DMRT. B: inoculation with Bradyrhizobium sp.; A: inoculation with Azospirillum basilenes 
branches per plant.

Concerning the effect of microbial inoculant results in Table 2 exhibited that, mixture inoculation was significantly increased number of branches and fresh and dry weight of plant compared to other treatment, Azospirillum inoculum scored tallest plants. On the other hand, the lowest recorded of the previous characters achieved from un-inoculated control. Similar results were reported by Hungria et al. (2010) for maize and wheat crops individually inoculated with Azospirillum strains which recorded an increase ranged from 24 to $30 \%$ and $13-18 \%$ in grain yields of maize and wheat as compared with non-inoculated control. In field experiments, the yield of maize and wheat raised up by 27 and $31 \%$, respectively by liquid and peat-based inoculants carrying a combination of $A$. brasilense strains. Such effects, duo to inoculation, could be attributed to general increments in uptake of various macro and micronutrients rather than to biologically fixed nitrogen. According to Turan et al. (2014), treated cabbage seedlings with PGPRs stimulate the growth in terms of fresh and dry weights of shoot and root, stem diameter, seedling height, chlorophyll values and leaf are as eedlings as compared with the un-inoculated control. Also, Ojeda-Quintana et al. (2016) found that inoculation of Megathyrsusmaximus seeds with Azospirillumlipoferum increased dry matter. They concluded that this biopreparation can be an alternative to mineral fertilization.

Data of Table 3 represent the interaction effect between bentonite amendments and bacterial inoculation on plant height, number of branches, fresh and dry weight of cowpea plants cultivated in sandy soil. There were significant interactions between treatments for above mentions traits. The highest characters obtained with adding 9 ton bentonite with mixture inoculation compared to individual inoculation by bradyrhizobium or Azospirillum. The promotive effect of mixture

TABLE 3. Effect of interaction between bentonite amendments and microbial inoculationon some vegetative growth of cowpea cultivated in sandy soil.

\begin{tabular}{|c|c|c|c|c|c|c|c|c|c|}
\hline \multirow{2}{*}{$\begin{array}{l}\text { Treatments } \\
\text { Bentonite } \\
\text { (ton/fed.) }\end{array}$} & \multirow[t]{2}{*}{ Bio. } & \multicolumn{2}{|c|}{$\begin{array}{l}\text { Plant height } \\
\text { (cm) }\end{array}$} & \multicolumn{2}{|c|}{ No. branches/plant } & \multicolumn{2}{|c|}{$\begin{array}{c}\text { Fresh weight } \\
\text { (g/plant) }\end{array}$} & \multicolumn{2}{|c|}{$\begin{array}{c}\text { Dry weight } \\
\text { (g/plant) }\end{array}$} \\
\hline & & $\begin{array}{c}1^{\text {st }} \\
\text { Season }\end{array}$ & $\begin{array}{c}2^{\text {nd }} \\
\text { Season }\end{array}$ & $\begin{array}{c}1^{\text {st }} \\
\text { Season }\end{array}$ & $\begin{array}{c}2^{\text {nd }} \\
\text { Season }\end{array}$ & $\begin{array}{c}1^{\text {st }} \\
\text { Season }\end{array}$ & $\begin{array}{c}2^{\text {nd }} \\
\text { Season }\end{array}$ & $\begin{array}{c}1^{\text {st }} \\
\text { Season }\end{array}$ & $2^{\text {nd }}$ Season \\
\hline \multirow{4}{*}{$\mathbf{0}$} & $\mathrm{C}$ & 59.221 & $65.52 \mathrm{i}$ & $2.75 \mathrm{~g}$ & $2.77 \mathrm{~h}$ & $109.89 \mathrm{i}$ & $118.90 \mathrm{~g}$ & $54.04 \mathrm{i}$ & $57.75 \mathrm{j}$ \\
\hline & B & $69.45 j$ & $70.91 \mathrm{~h}$ & $2.69 \mathrm{~g}$ & $2.75 \mathrm{~h}$ & $126.04 \mathrm{~g}$ & $132.19 \mathrm{f}$ & $59.11 \mathrm{i}$ & $62.69 \mathrm{hi}$ \\
\hline & A & 74.87ehfg & $76.75 \mathrm{ef}$ & $2.85 \mathrm{fg}$ & $3.04 \mathrm{~g}$ & $160.15 \mathrm{e}$ & $165.27 \mathrm{~d}$ & $59.29 \mathrm{~h}$ & $61.72 \mathrm{i}$ \\
\hline & $\mathbf{M}$ & 72.71ihg & $75.98 \mathrm{efg}$ & $3.03 \mathrm{f}$ & $3.08 \mathrm{~g}$ & $148.63 \mathrm{f}$ & $157.02 \mathrm{e}$ & $65.02 \mathrm{fg}$ & $68.94 \mathrm{de}$ \\
\hline \multirow{4}{*}{3} & $\mathbf{C}$ & $66.33 \mathrm{k}$ & $66.66 \mathrm{i}$ & $2.66 \mathrm{~g}$ & $2.85 \mathrm{gh}$ & $118.79 \mathrm{~h}$ & $128.56 \mathrm{f}$ & $57.77 \mathrm{~h}$ & 63.60ghi \\
\hline & B & 74.41ihfg & 77.94de & $3.32 \mathrm{e}$ & $3.36 \mathrm{f}$ & $159.97 \mathrm{e}$ & $164.86 \mathrm{~d}$ & $63.60 \mathrm{~g}$ & $65.55 \mathrm{fg}$ \\
\hline & $\mathbf{A}$ & $76.34 \mathrm{efd}$ & $78.23 \mathrm{edc}$ & $3.62 \mathrm{~d}$ & $3.65 \mathrm{e}$ & $162.40 \mathrm{e}$ & $164.44 d$ & $63.60 \mathrm{~g}$ & $64.45 \mathrm{gh}$ \\
\hline & $\mathbf{M}$ & $79.86 \mathrm{ab}$ & $80.64 \mathrm{~b}$ & $3.68 \mathrm{~cd}$ & $3.80 \mathrm{ed}$ & $173.93 \mathrm{~d}$ & $180.52 \mathrm{c}$ & $65.76 \mathrm{efg}$ & $67.52 \mathrm{ef}$ \\
\hline \multirow{4}{*}{6} & $\mathbf{C}$ & $72.22 \mathrm{i}$ & $74.26 \mathrm{~g}$ & $3.78 \mathrm{bcd}$ & $3.85 \mathrm{cde}$ & $179.34 \mathrm{c}$ & $188.40 \mathrm{~b}$ & $68.77 \mathrm{bcd}$ & $70.41 \mathrm{~cd}$ \\
\hline & B & $72.56 \mathrm{ih}$ & $75.11 \mathrm{fg}$ & $3.55 \mathrm{ed}$ & $3.80 \mathrm{ed}$ & $174.78 \mathrm{~d}$ & $179.67 \mathrm{c}$ & $68.34 \mathrm{cde}$ & $70.29 \mathrm{~cd}$ \\
\hline & $\mathbf{A}$ & $75.97 \mathrm{ef}$ & $77.56 \mathrm{de}$ & $3.71 \mathrm{~cd}$ & $3.89 \mathrm{cde}$ & $179.30 \mathrm{c}$ & $181.48 \mathrm{c}$ & $66.53 \mathrm{def}$ & $69.17 \mathrm{de}$ \\
\hline & $\mathbf{M}$ & $78.44 \mathrm{bcd}$ & $80.33 \mathrm{cb}$ & $4.03 \mathrm{ab}$ & $4.14 \mathrm{ab}$ & $185.15 b$ & $188.34 \mathrm{~b}$ & $71.15 \mathrm{ab}$ & $73.42 \mathrm{~b}$ \\
\hline \multirow{4}{*}{9} & C & $75.04 \mathrm{efg}$ & $77.75 \mathrm{de}$ & $3.74 \mathrm{~cd}$ & $3.95 \mathrm{bcd}$ & $182.78 \mathrm{bc}$ & $189.33 b$ & $69.51 b c$ & $70.74 \mathrm{bcd}$ \\
\hline & B & $77.15 \mathrm{ecd}$ & $79.85 \mathrm{bcd}$ & $3.89 \mathrm{bc}$ & $4.04 \mathrm{abc}$ & $184.42 b$ & $189.53 b$ & $70.69 \mathrm{abc}$ & $72.54 b c$ \\
\hline & A & $79.28 \mathrm{bc}$ & $81.23 b$ & $4.02 \mathrm{ab}$ & 4.10abc & $186.85 \mathrm{ab}$ & $190.84 b$ & $69.77 \mathrm{bc}$ & $72.78 \mathrm{bc}$ \\
\hline & $\mathbf{M}$ & $82.11 \mathrm{a}$ & $83.77 \mathrm{a}$ & $4.20 \mathrm{a}$ & $4.28 \mathrm{a}$ & $190.70 \mathrm{a}$ & $201.86 \mathrm{a}$ & $72.84 \mathrm{a}$ & $77.47 \mathrm{a}$ \\
\hline \multicolumn{2}{|c|}{ LSD at $5 \%$} & 2.443 & 2.294 & 0.274 & 0.245 & 4.461 & 4.839 & 2.618 & 2.704 \\
\hline
\end{tabular}

In a column means followed by a common letter are not significantly different at $5 \%$ level by DMRT. C: Control; B: inoculation with Bradyrhizobium sp.; A: inoculation with Azospirillum basilenes; M: Mixture.

inoculation demonstrated by many investigators (El-Howeity 2008 and El-Howeity et al. 2009)

Considering the mixture incubation, Parmar and Dufresne (2011) mentioned that the positive effect of combined inoculation of Azotobacterand

Env. Biodiv. Soil Security Vol. 3 (2019)
Rhizobium sp. showed significantly improve the nodulation status. The synergistic interactions between host and Azotobacter sp. was enhanced due to increasing nitrogen content in roots and shoots of respiring/metabolizing plant cells which improves various conditions within 
the rhizosphere. In open field conditions, the improvement of growth yields in various soil mineral compositions was shown by both Azotobacter and Azospirillum which declare a mutualistic relationship established between Azotobacter and Azospirillum to interact with Rhizobium leading to enhancement in chick pea yields. Also, Mishra et al. (2012) pointed out that, co-inoculation of PGPRs with Rhizobium leguminosarum significantly increased nodulation and plant biomass by 156.2 and $57.1 \%$, respectively. Furthermore, co-inoculation enhanced total chlorophyll content, available iron, total iron, leghaemoglobin, $\mathrm{N}, \mathrm{P}$ and $\mathrm{K}$ uptake of shoots by $31.5,106.7,95.9,17.5,66.3$, 23.3 and $47.1 \%$, respectively, as compared with uninoculated control.

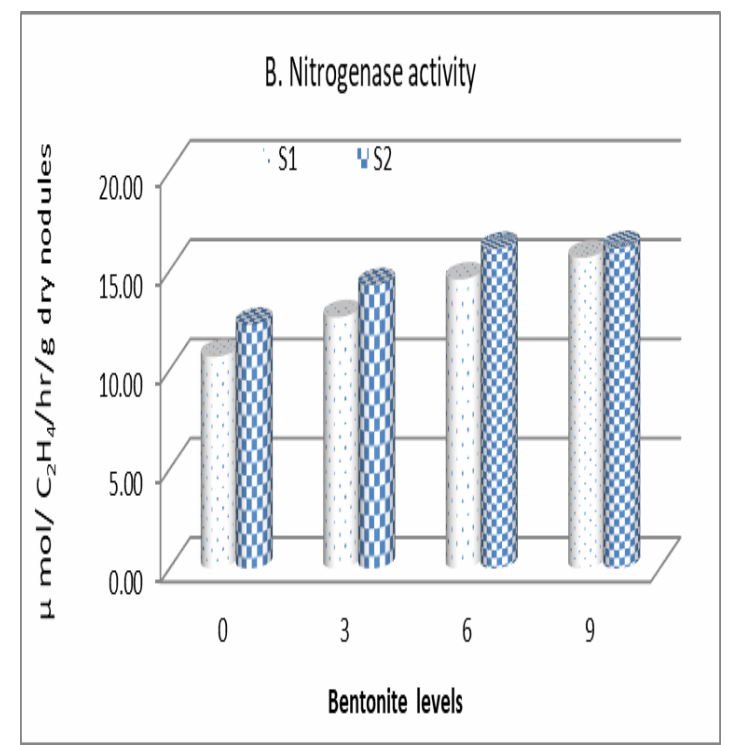

Nitrogenase and dehydrogenase activities

Nitrogen fixation $\left(\mathrm{N}_{2}\right.$-ase) of cowpea root nodules and dehydrogenase activity in the rhizosphere as affected by bentonite amendments and microbial inoculation and their interactions are illustrated in Fig. 1,2 and 3. Figure 1 showed significant increases with increasing bentonite amendments which stimulated microbial activity in soil, the highest activity of $\mathrm{N}_{2}$-ase and DHA were found by adding $9 \mathrm{t} / \mathrm{fed}$ in two seasons. It recorded 15.65 and $16.13 \mu \mathrm{mol} / \mathrm{C}_{2} \mathrm{H}_{4} / \mathrm{h} / \mathrm{g}$ dry nodules for $\mathrm{N}_{2}$-ase and 38.07and $40.40 \mu \mathrm{g}$ TPF/g dry soil/h for DHA, during 2015 and 2016 growing seasons, respectively. On the other hand, the lowest values were scored with control (0 bentonite). Incorporation bentonite improved physical and chemical soil properties. Results illustrated in Fig. 3 show the relationship between incorporation bentonite and biofertilizers with microbial activities DHA and $\mathrm{N}_{2}$-ase activity

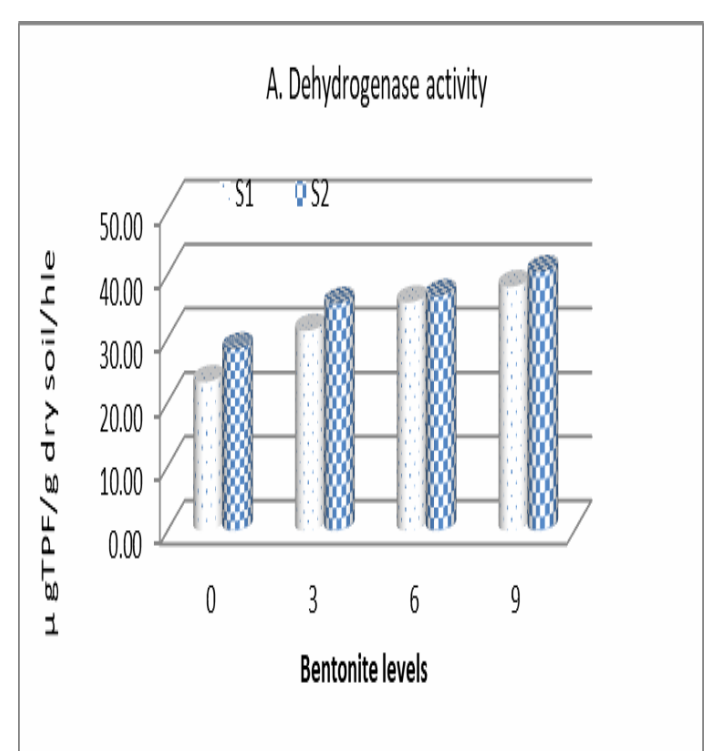

Fig. 1. Effect of bentonite amendments on DHA in soil (A), and $\mathrm{N}_{2}-$ ase activity in root nodules of cowpea plants (B).
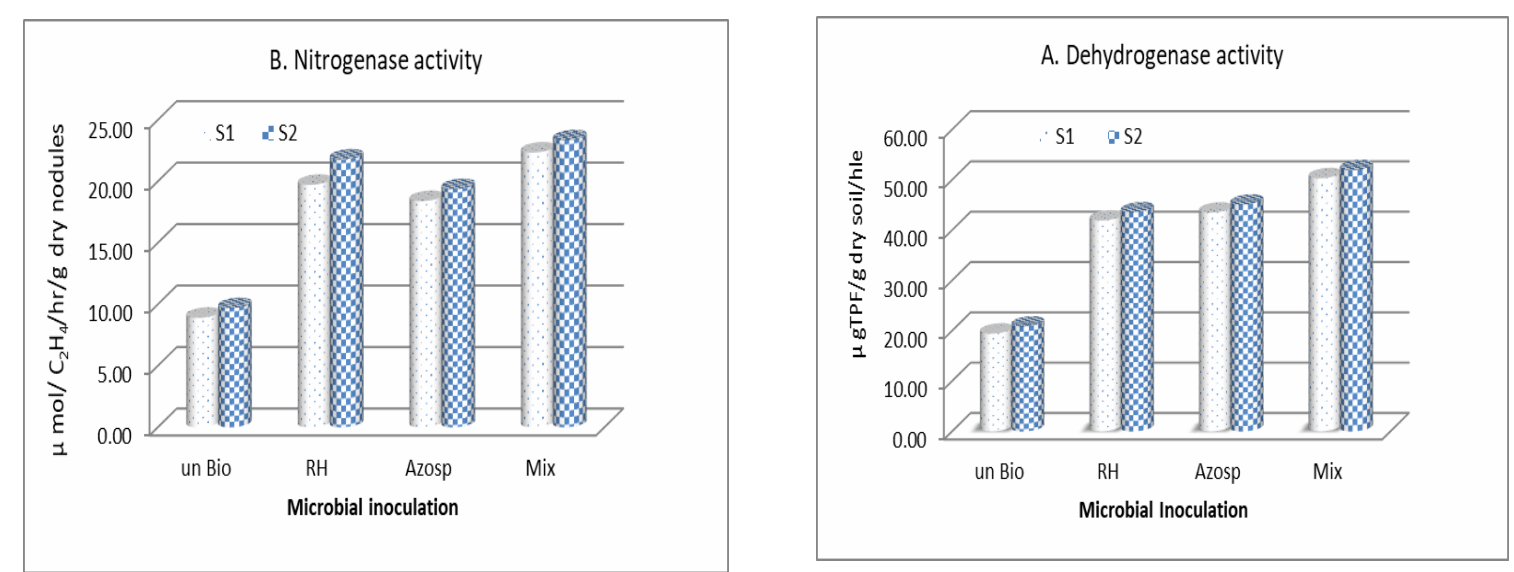

Fig. 2. Effect of microbial inoculation on DHA in soil (A), and $\mathrm{N}_{2}$-ase activity in root nodules of cowpea plants (B). RH: inoculation with Bradyrhizobium sp.; Azosp: inoculation with Azospirillum basilenes. 

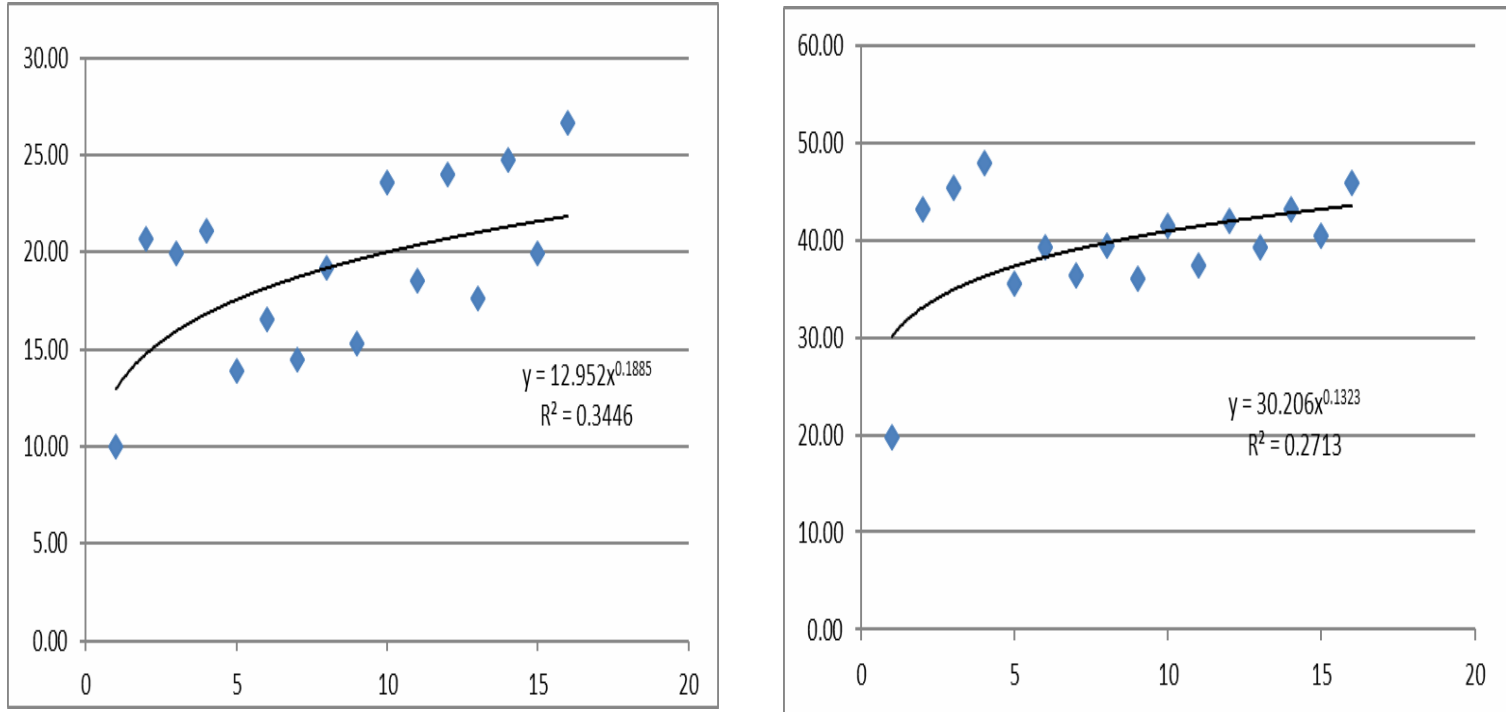

Fig. 3. Effect of interaction between treatments on DHA activity in the rhizosphere of cowpea plants (A); and $\mathrm{N}_{2}-$ ase activity in root nodules of cowpea plants $(B)$.

in the rhizosphere. The obtained coefficients of determination $\left(\mathrm{R}^{2}\right)$ were liner relationships where $\mathrm{R}^{2}$ values ranging 0.27 and 0.34 with DHA and $\mathrm{N}_{2}$-ase activity, respectively.

These results are in harmony with those obtained by Umer and Rajab (2012) were found that, application of organic matter to soil enhancement soil aggregate and caused positive correlation between soil respirations, microbial biomass with soil aggregate stability. Also, Mi et al. (2017) show bentonite amendments significantly increased above-ground biomass from 2 to $39 \%$ and grain yield from 3 to $20 \%$, as well as improved water use efficiency $29 \%$ through five years.

Concerning the effect of microbial inoculation on enzyme activities are presented in Fig. 2, inoculation by bradyrhizobium sp. or Azospirillum significantly increased soil enzyme activity. The highest activity was significantly with the treatment co-inoculation compared to single inoculation and uninoculated. Increases above control with co-inoculation were 150.4, $140.86,158.76$ and $149.35 \%$ for $\mathrm{N}_{2}$-ase and DHA activity in two seasons, respectively. Concerning the effect of interaction between bentonite and biofertilizers, there were significant interactions between treatments for two enzyme activity. The best interaction was found with co-inoculation and 9 ton bentonite amendment, which gave 25.56, Env. Biodiv. Soil Security Vol. 3 (2019)

$27.66 \mu \mathrm{mol} / \mathrm{C}_{2} \mathrm{H}_{4} / \mathrm{h} / \mathrm{g}$ dry nodules and 50.93, $54.57 \mu \mathrm{gTPF} / \mathrm{g}$ dry soil/h for $\mathrm{N}_{2}$ - ase and DHA in two seasons, respectively. Also, Fig. 3 shows the correlation positive between soil amendment and enzyme activity in the rhizosphere. Similar results were also reported by Tallai (2011) who studied the effect of bentonite and zeolite on microbial activity in sandy soil. Who found that, adding bentonite at rate $10 \mathrm{t} / \mathrm{ha}^{-1}$ and zeolite at rate $5 \mathrm{t} / \mathrm{ha}^{-1}$ increased total microbial count and stimulated enzyme activities, urease, phosphatase in sandy soil. Jarvan et al. (2014) showed that addition of organic matter increased DHA in soil by $22.7 \%$ over control. In this concern, ElHoweity and Abdel Gawad (2017) found that, mixed inoculation with Bradyrhizobium and cyanobacteria improved dehydrogenase activity in the rhizosphere of soybean plants under field conditions.

\section{Yield of cowpea plants}

The response of cowpea yield and its attributes to bentonite amendments and microbial inoculation by Bradyrhizibiom sp. or Azospirillum sp. and co-inoculation are illustrated in Tables 4 and 5. Results showed that cowpea seed and straw yield and 100 seed weight were significantly affected by bentonite amendment. Increasing bentonite rates from 3 to 6 up to $9 \mathrm{t} / \mathrm{fed}$ caused 
TABLE 4. Effect of bentonite amendments and microbial inoculation on yield of cowpea cultivated in sandy soil.

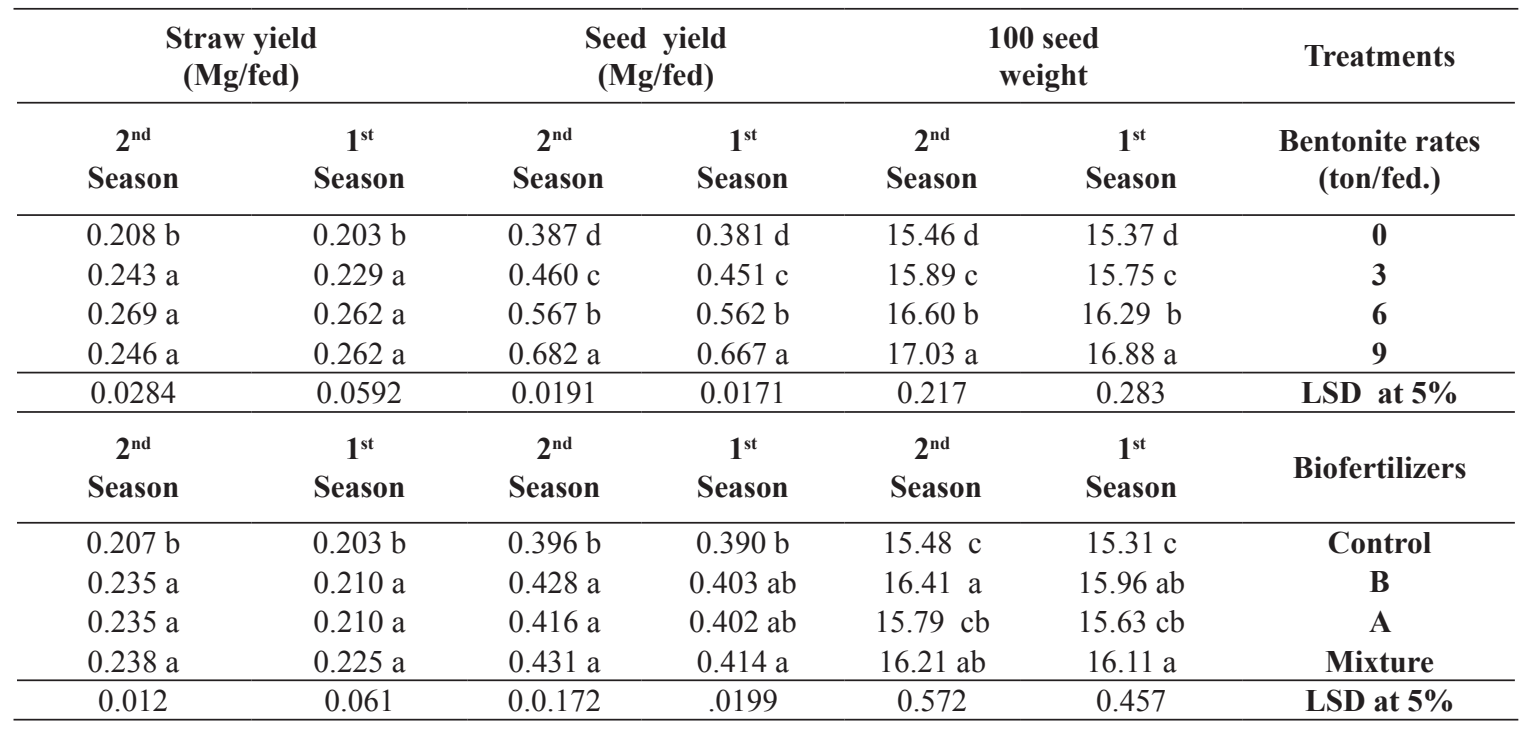

In a column means followed by a common letter are not significantly different at $5 \%$ level by DMRT. B: inoculation with Bradyrhizobium sp.; A: inoculation with Azospirillum basilenes.

TABLE 5. Effect of interaction between bentonite amendments and microbial inoculation on yield of cowpea cultivated in sandy soil.

\begin{tabular}{|c|c|c|c|c|c|c|c|}
\hline \multicolumn{2}{|c|}{$\begin{array}{c}\text { Straw yield } \\
(\mathrm{Mg} / \mathrm{fed})\end{array}$} & \multicolumn{2}{|c|}{$\begin{array}{l}\text { Seed yield } \\
\text { (Mg/fed) }\end{array}$} & \multicolumn{2}{|c|}{100 seed weight } & \multirow{3}{*}{ Bio. } & Treatments \\
\hline $2^{\text {nd }}$ & $1^{\text {st }}$ & $2^{\text {nd }}$ & $1^{\text {st }}$ & $2^{\text {nd }}$ & $1^{\text {st }}$ & & \multirow{2}{*}{$\begin{array}{l}\text { Bentonite } \\
\text { (ton/fed.) }\end{array}$} \\
\hline Season & Season & Season & Season & Season & Season & & \\
\hline $0.187 \mathrm{~g}$ & $0.219 \mathrm{~d}$ & $0.387 \mathrm{j}$ & $0.381 \mathrm{i}$ & $15.48 \mathrm{~h}$ & $15.31 \mathrm{~h}$ & $\mathrm{C}$ & \multirow{4}{*}{ 0 } \\
\hline $0.235 \mathrm{f}$ & $0.210 \mathrm{~d}$ & $0.428 \mathrm{i}$ & $0.409 \mathrm{hi}$ & $15.59 \mathrm{~h}$ & $15.53 \mathrm{gh}$ & B & \\
\hline $0.235 \mathrm{f}$ & $0.210 \mathrm{~d}$ & $0.420 \mathrm{i}$ & $0.407 \mathrm{hi}$ & $15.63 \mathrm{~h}$ & $15.61 \mathrm{~g}$ & $\mathbf{A}$ & \\
\hline 0.245 ef & $0.222 \mathrm{~d}$ & $0.429 \mathrm{i}$ & $0.416 \mathrm{hi}$ & $16.17 \mathrm{f}$ & $16.02 \mathrm{f}$ & M & \\
\hline $0.243 \mathrm{ef}$ & $0.229 \mathrm{~cd}$ & $0.460 \mathrm{~h}$ & $0.451 \mathrm{gh}$ & $15.89 \mathrm{~g}$ & $15.75 \mathrm{~g}$ & $\mathbf{C}$ & \multirow{4}{*}{3} \\
\hline $0.289 \mathrm{bcd}$ & $0.285 \mathrm{ab}$ & $0.552 \mathrm{f}$ & $0.515 \mathrm{f}$ & $16.36 \mathrm{f}$ & 16.04 ef & B & \\
\hline $0.300 \mathrm{abc}$ & $0.286 \mathrm{ab}$ & $0.510 \mathrm{~g}$ & $0.500 \mathrm{gf}$ & $16.24 \mathrm{f}$ & $16.00 \mathrm{f}$ & $\mathbf{A}$ & \\
\hline $0.315 \mathrm{abc}$ & $0.310 \mathrm{a}$ & $0.573 \mathrm{e}$ & $0.569 \mathrm{~cd}$ & $16.66 \mathrm{e}$ & $16.26 \mathrm{ed}$ & M & \\
\hline $0.269 \mathrm{de}$ & $0.262 \mathrm{bc}$ & $0.567 \mathrm{ef}$ & $0.562 \mathrm{ed}$ & $16.74 \mathrm{e}$ & $16.30 \mathrm{~cd}$ & $\mathrm{C}$ & \multirow{4}{*}{6} \\
\hline $0.303 \mathrm{abc}$ & $0.304 \mathrm{a}$ & $0.601 \mathrm{~d}$ & $0.586 \mathrm{~cd}$ & $17.07 \mathrm{~d}$ & $16.91 \mathrm{~b}$ & B & \\
\hline $0.290 \mathrm{bcd}$ & $0.286 \mathrm{ab}$ & $0.592 \mathrm{~d}$ & $0.513 \mathrm{f}$ & $16.86 \mathrm{de}$ & $16.52 \mathrm{c}$ & $\mathbf{A}$ & \\
\hline $0.308 \mathrm{abc}$ & $0.308 \mathrm{a}$ & $0.682 \mathrm{a}$ & $0.667 \mathrm{a}$ & $17.65 \mathrm{~b}$ & $17.40 \mathrm{a}$ & $\mathbf{M}$ & \\
\hline 0.246 ef & $0.262 \mathrm{bc}$ & $0.628 \mathrm{c}$ & $0.617 \mathrm{bc}$ & $17.03 \mathrm{~d}$ & $16.88 \mathrm{~b}$ & $\mathrm{C}$ & \multirow{4}{*}{9} \\
\hline $0.316 \mathrm{ab}$ & $0.308 \mathrm{a}$ & $0.662 \mathrm{~b}$ & $0.652 \mathrm{ab}$ & $17.35 \mathrm{c}$ & $17.10 \mathrm{~b}$ & B & \\
\hline $0.288 \mathrm{bcd}$ & $0.313 \mathrm{a}$ & $0.662 \mathrm{~b}$ & $0.659 \mathrm{ab}$ & $17.32 \mathrm{c}$ & $17.01 \mathrm{~b}$ & $\mathbf{A}$ & \\
\hline $0.324 \mathrm{a}$ & $0.316 \mathrm{a}$ & $0.682 \mathrm{a}$ & $0.679 \mathrm{a}$ & $18.02 \mathrm{a}$ & $17.39 \mathrm{a}$ & M & \\
\hline 0.0283 & 0.0335 & 0.0174 & 0.048 & 0.241 & 0.246 & & at $5 \%$ \\
\hline
\end{tabular}

In a column means followed by a common letter are not significantly different at $5 \%$ level by DMRT. C: Control; B: inoculation with Bradyrhizobium sp.; A: inoculation with Azospirillum basilenes; M: Mixture

significant increases in seed yield ( $\mathrm{t} / \mathrm{fed})$ and 100 seed weight. In the other hand, increases in straw yield were significant compared to control but insignificant increases between bentonite levels.

Increases in seed yield may be introduction bentonite to soil improve physical, chemical soil properties for cowpea plants and bentonite contain organic matter $1.12 \%$, total nitrogen $0.064 \%$ and other trace elements (Table 1) which enhancement plant growth and increase the yield of cowpea. These results are in harmony with Env. Biodiv. Soil Security Vol. 3 (2019) 
those obtained by Junzhen et al. (2017) mentioned that, adding bentonite increased plant growth and grain yield. In this respect, Arafa et al. (2015) found that, application of bentonite at rate 12 ton/ fed significantly increased all vegetative growth characters and yield of cowpea cultivars grown in sandy soil.

The response of cowpea yield and its attributes to inoculation with Bradyrhizobium and Azospirillumindividually and co-inoculation is listed in Table 4. Results showed that cowpea yield and its attributes were significantly affected by microbial inoculation. Co-inoculation with Bradyrhizobium and Azospirillum caused highly significant increases in seed yield (ton/fed), straw yield (ton /fed) and 100 seed weight $(\mathrm{g})$ in the $2^{\text {nd }}$ season. Results of the interaction effect between bentonite amendment and microbial inoculation on the above characters of cowpea are presented in Table 5. The highest total seed yield of cowpea was recorded from use the co-inoculation with $9 \mathrm{Mg} / \mathrm{fed}$ which was $0.679,0.682,0.316,0.324$ $\mathrm{Mg} / \mathrm{fed}$ for seed and straw yield in the two growing seasons, respectively. However, these increases were pronounced with adding 6 ton bentonite with co-inoculation gave $0.667,0.682$, 0.308 and $0.308 \mathrm{Mg} /$ fed for seed and straw yield in two seasons, respectively. In this concern, El- Howeity (2008) found fresh and dry weights of shoot and root of phaseolus plants as well as improvement the ability for water absorption increased due to Azospirillum inoculation. Zahir (2011) referred that co-inoculation increased lentil growth, nodulation and yield compared to single inoculation under pot and field conditions. Also, El-Howeity (2012) found that the application of yeast and Aminokem as bio-organic amendments with or without mineral fertilizers showed increases in $\mathrm{N}, \mathrm{P}, \mathrm{K}$ contents and $\mathrm{Ca}$ in leaves of Valencia orange seedlings. Abdel-Aziz (2013) reveled that using microbial inoculation with Azospirillum sp., Trichoderma sp. Bacillus megaterium and Pseudomonas fluorescens as mixtures enhanced cowpea yield and its attributes compared to single inoculation and control. This result agreed with the study of Chatterjee and Bandyopadhyay (2017) in that the inoculation of cowpea with (Rhizobium + PSB) significantly increased the growth and yield compared to uninoculated plants.

\section{Conclusion}

Microbial inoculation with mixture of Bradyrhizobium and Azospirillum as well as Env. Biodiv. Soil Security Vol. 3 (2019) addition of 9 ton/fed bentonite as a soil amendment significantly increased vegetative growth, enzymes activity and yield of cowpea plants cultivated in sandy soil in both growing seasons compared to control. The over-all results of the present study suggest that microbial inoculation and bentonite amendment could be improving crop growth and improve sandy soil fertility.

\section{References}

Abdel Aziz M.A. and Salem M.F. (2013) Effect of microbial inoculation on reduction of cowpea chemical fertilizers under newly reclaimed soils condition in Egypt. J. Plant Production, Mansoura Univ., 4(5), 745-761.

Arafa M.M., Darwish W.M. and El-Howeity M.A. (2015) Effect of water use efficiency and bentonite levels on growth, yield and chemical composition of seeds for cowpea (Vignaunguiculata L.) cultivars grown in sandy soil. Annals of Agric. Sci. Moshtohor, 53(4), 667-678.

Asady G.H., Smucker A.J.M. and Adams M.W. (1985) Seedling test for the quantitative measurement of root tolerances to compacted soil. Crop Sci., 25, 802-1985.

Benkhelifa M., Belkhodje M., Daoud Y. and Tessier D. (2008)Effect of Maghnian bentonite on physical properties of sandy soils under semi-arid Meditrranean climate.Pak. J. Biol. Sci., 11(1), 1725.

Chatterjee R. and Bandyopadhyay S. (2017)Effect of boron, molybdenum and biofertilizers on growth and yield of cowpea (Vignaunguiculate L. Walp.) in acid soil of eastern Himalayan region. J. of the Saudi Soc. of Agric. Sci., 16, 332-336.

El-Howeity M.A. (2008)Diazotrophy and growth of beans (Phaseolus vulgaris) genotypes inoculated with rhizobia and lactic acid bacteria. Minufiya J. Agric. Res., 33(1), 211-230.

El-Howeity M.A. (2012)Utilization of bio-organic compounds and mineral fertilizer to improve growth, nutrient content in leaves of Valencia orange seedlings grown in desert land. Egypt. J. Hort., 39(1), 31-43.

El-Howeity M.A. and Abdel-Gawad Sh. A. (2017) Response of soybean plants to inoculation with rhizobia and cyanobacteria. Menoufia J. Soil Sci., 2, $135-144$.

El-Howeity M.A., Abdalla A.A., Abo-Kora H. A. 
and El-Shinnawi M.M. (2009) Response of faba bean plants to inoculation with Rhizobium leguminosarium and other Rhizobacteria under three nitrogen levels in newly reclaimed soil. $J$. Agric. Sci. Mansoura Univ., 34(6), 7259-7272.

FAO (2013) Agriculture Rome, (2015) Available in: http: //faostat3. fao.org /faostat /collections? Subset=agriculture. Accessed at: June. 96, 9, 12751284.

Friedel J.K., Molter K. and Fischer, W.R. (1994) Comparison and improvement of methods for determining soil dehydrogenase activity by using triphenyltetrazolium chloride and iodo nitro tetrazolium chloride. Biol. Fertil. Soils, 18, 291-296

Gzaban J., Siebielec G., Czyz E. and Niedzwieck J. (2013) Effect of bentonite addition on sandy soil chemistry in a long -term plot Experiment (1): effect on organic carbon and total nitrogen. Pol. J. Environ. stud., 22(6), 1661- 1667.

Hungria M., Campo R.J., Souza E.M., Pedrosa F.O. (2010) Inoculation with selected strains of Azospirillumbrasilense and A. lipoferum improves yields of maize and wheat in Brazil. Plant Soil, $331,413-425$

Järvan M., Edesi L., Adamson A., Võsa T. (2014) Soil microbial communities and dehydrogenase activity depending on farming systems. Plant Soil Environ.,60 (10), 459-463.

Junzhen Mi., Edward G., Shengtao, Xu. and Neil M. (2017) Effect of bentonite amendment on soil hydraulic parameters and millet crop performance in a semi-arid region. Field Crops Research, 212,107-114.

Kloepper j.andSchroth M.N. (1978). Plant growthpromoting rhizobacteria on radishes. Pages 879882 in Proc. I $V^{\text {th }}$ international conference on plant pathogenic bacteria .2, Angers, France.

Mi J., Edward G., GregorichShengtaoXu., McLaughlin N.B., Ma B., Liu J. (2017) Effect of bentonite amendment on soil hydraulic parameters and millet crop performance in a semi-arid region. Field Crops Research, 22, 107-114.

Mishra P.K., Bisht S.B., Mishra S., Selvakumar G., Bisht J.K., and Gupta H.S. (2012) Coinoculation of Rhizobium Leguminosarum Pr1 With A cold tolerant Pseudomonas Sp. improves iron acquisition, nutrient uptake and growth of field pea (Pisumsativum L.). J. of Plant Nutrition, 35, 243-256.
Ojeda-Quintana L.J., Toledo-Vazquez L., HernándezRodríguez C., Machado-DíazY..and Gómez E.F. (2016). The influence of application of Azospirillumlipoferum in Megathyrsusmaximusvc. guineatobiatá in Pardo Grisáceo soil. Pastos y Forrajes, 39 (1),27-32.

Omara A., Hauka F., Afify A., Nour El-Din M., Kassem M. (2017) The Role of Some PGPR Strains to BiocontrolRhizoctoniaSolani in Soybean and Enhancement The Growth Dynamics and Seed Yield. Environ. Biodiv.\& Soil Security, 1, 47 - 59.

Page, A.L., Miller R.H. and Keeney D.R. (1982) Methods of soil analysis; 2.Chemical and microbiological properties, 2.Aufl. 1184 S., American Soc. of Agronomy (Publ.), Madison, Wisconsin, USA, gebunden 36 Dollar.

ParmarN., and Dufresne J. (2011) Beneficial Interactions of Plant Growth Promoting Rhizosphere Microorganisms. In: A. Singh et al. (eds.), Bioaugmentation, Biostimulation and Biocontrol. Springer Heidelberg Dordrecht London New York.

Shalabey O.E., Araf, M.M. and Bayourai N.A. (2005) Utilization some soil amendments a source of micronutrients in soil and their effect on yield of cowpea plants (Vignaunguiculata L.) in newly reclaimed soil. Annals of Agric. Sc., Moshtohor, 43(3), 1357-1373.

Stone J.A. (1985). Poorly drained conditions and root development of eight indeterminate soybean cultivars. Agron.J., 77,787-789.

Tallai M. (2011). Effect of bentonite and zeolite on characteristics and change of microbial activity of acidic humic sandy soil. Pol. J. Environ. Stud., 26, $1-8$.

Tejada, M., Gomez, I., Garcia-Martinez A., Osta P. and Parado J. (2011)Effects of prochloraz fungicide on soil enzymatic activities and bacterial communities. Ecotoxicology \& Environmental Safety, 74, 17081714.

Tilak K. V., Ranganayaki, B. R., Saxena, A. K.,Nautiya C. S., Shilpi M., Tripathi A. K. and Johri B. N. (2005). Diversity of plant growth and soil health supporting bacteria. Current Science, 89(1), 126149.

Turan M., Melek E., Ertan Y., Adem G., Kenan K., Recep K., Atilla D. (2014). Plant growth-promoting rhizobacteria improved growth, nutrient, and hormone content of cabbage (Brassica oleracea) seedlings. Turk. J. Agric. For., 38: 327-333.

Env. Biodiv. Soil Security Vol. 3 (2019) 
Turner G.L. and Gibson A.H. (1980) Measurement of nitrogen fixation by indirect means. Pp. 111-138 in 'Methods for Evaluating Biological Nitrogen Fixation', ed by F.J. Bergersen. John Wiley \& Sons Ltd: Chichester, New York.

Umer M. I. and Rajab S.M. (2012) Correlation between aggregate stability and microbiological activity in two Russian soil types. Eurasian J. Soil Sci., 6, 4550.

Wolińska A. and Stępniewska Z. (2011)Microorganisms abundance and dehydrogenase activity as a consequence of soil reoxidation process, In: Soil Tillage \& Microbial Activities, M. Miransari, (Ed.), 111-143, Research Singpost, Kerala, India.
Xie W., Zhou J., Wang H., Chen X., Lu Z., Yu J. and Chen X. (2009) Short-Term Effects of Copper, Cadmium and Cypermethrin On Dehydrogenase Activity and Microbial Functional Diversity. In Soils After LongTerm Mineral or Organic Fertilization. Agriculture, Ecosystems \& Environment, 129, 450-456.

Zahir A. Z., Zafar-ul-Hye M., Sajjad S. and Naveed M. (2011) Comparative effectiveness of Pseudomonas and Serratia sp. containing ACC-deaminase for coinoculation with Rhizobium leguminosarum to improve growth, nodulation, and yield of lentil. Biol Fertil. Soils.47, 457-465.

(Received 25/2/2019; accepted 18/4/2019) 